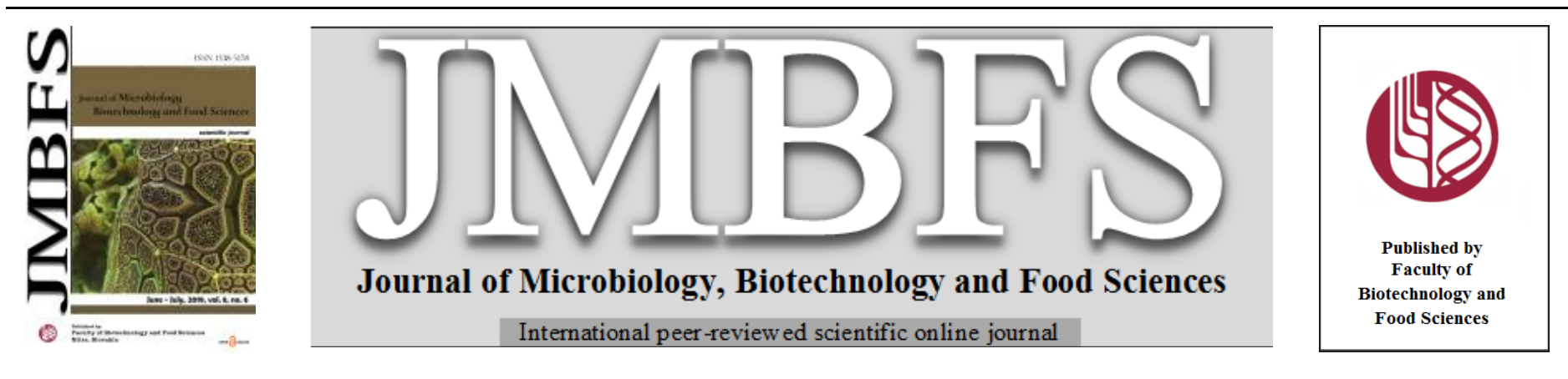

\title{
BARLEY VARIETIES DISCRIMINATION USING MALDI-TOF MASS SPECTROMETRY
}

\author{
Lukas Hleba ${ }^{1}$, Stefan Drab ${ }^{2}$, Miroslava Cisarova ${ }^{3}$, Juraj Cubon ${ }^{4}$
}

Address(es): Ing. Lukáš Hleba, PhD.,

${ }^{1}$ Slovak University of Agriculture in Nitra, Faculty of Biotechnology and Food Science, Department of Microbiology, Tr. Andreja Hlinku 2, 94976 Nitra, Slovakia. ${ }^{2}$ Slovak University of Agriculture in Nitra, Faculty of Biotechnology and Food Science, Department of Storing and Processing of Plant Products, Tr. Andreja Hlinku 2, 94976 Nitra, Slovakia.

${ }^{3}$ University of SS. Cyril and Methodius, Faculty of Natural Sciences, Department of Biology, Nám. J. Herdu 2, Trnava, Slovakia.

${ }^{4}$ Slovak University of Agriculture in Nitra, Faculty of Biotechnology and Food Science, Department of Animal Products Evaluation and Processing, Tr. Andreja Hlinku 2, 94976 Nitra, Slovakia.

*Corresponding author: lukas.hleba@gmail.com

doi: 10.15414/jmbfs.2019.8.6.1347-1351

\section{ARTICLE INFO}

Received 7. 11.2018

Revised 9. 1. 2019

Accepted 22. 1. 2019

Published 1. 6. 2019

Regular article open $\partial$ ACcESS

\begin{abstract}
Barley is a widely used foodstuff and it is the most important component in malting and brewing. Purity of barley grains in malting and brewing is important in relation to technological processing. Therefore, an effective analysis of barley purity has high priority. The aim of this study was the discrimination of barley varieties using Matrix Assisted Laser Desorption/Ionization Time-of-flight Mass Spectrometry (MALDI-TOF MS). Eight barley varieties, Kangoo, Laudis, Malz, Marthe, Odyssey, Overture, Sebastian and Wintmalt were investigated. Several protein extraction methods, barley samples preparation for MALDI-TOF MS, reproducibility, influence of time on the hordein quality spectrum and groups of hordeins mass spectrum suitable for barley discrimination were tested. The results showed that removal of albumins and globulins does not affect the resulting hordein spectrum, but time decreases the hordein spectrum intensity. Preparation of barley samples has the highest priority. The most important factor is the selection of the right matrix and its use. B hordeins should be used for the discrimination of Barley varieties. Local Barley database based on B hordeins can be created but the protein spectra must be obtained with the highest purity and the highest reproducibility. The right set up of MALDI Biotyper software can lead to local Barley database establishment. Also, Barley's B hordeins were used for the creation of a relatedness dendrogram. These obtained results showed that MALDI-TOF MS is a very usefull and powefull method for Barley varieties discrimination with a high reproducibility.
\end{abstract}

Keywords: Barley, B hordeins, discrimination, MALDI-TOF MS

\section{INTRODUCTION}

Barley (Hordeum vulgare L.) is widely utilized as a food and feed, but its most economically important use is connected to malting and brewing (Eagles et al. 1995). Assessment of malt barley quality begins shortly after harvest and can involve a number of subsequent verifications depending on its direct delivery from the field to a malt house. The initial assessment will determine the suitability of a sample for malting. Analyses cover a range of physical, biochemical and metabolic characteristics (Izydorczyk and Edney 2016). From the different quality parameters reported in the literature, hot-water extract, kernel size fractions, kernel weight, $\beta$-glucan and protein contents, malting losses, friability, $\alpha$-amylase activity, viscosity, and soluble nitrogen ratio are common assays used to test the quality of barley mutants (Fox et al. 2003). A very important assessment in determining the suitability of a sample for malting is to verify the variety and varietal purity of a barley sample. Each variety differs in its malting potential, processing characteristics and malting quality. Maltsters require specific varieties to meet the customer's malt specification. Varietal purity is an important assessment as varietal mixtures generally process poorly with each variety requiring specific processing conditions to realize the variety`s fill potential and its ability to produce the best-quality malt possible without excessive malt losses. In the past the variety purity has been assessed by visual inspection but the proliferation of malting varieties has reduced the effectiveness of a visual inspection (Izydorczyk and Edney 2016; Shewry et al. 1980). It is highly important to have methods that can accurately and rapidly identify barley cultivars for the different end-use requirements. These methods are also needed for germplasm screening and genotype identification in barley breeding programs (Yan et al. 2003). To date the methods for quantitative and visual identification of barley cultivars are limited because numerous morphological, physiological and technological characters of the different genotypes are not stable in a given environment (Montembault et al. 1993). Polyacrylamide gel electrophoresis
(PAGE) and high-performance liquid chromatography (HPLC) are the most common protein-based methods for the protein separation, characterization and varietal identification in barley (Yan et al. 2003; Montembault et al. 1993) Although electrophoresis is very successful in varietal identification, it is only one of many other procedures, the results of which must be considered in combination with electrophoretic patterns (Shewry et al. 1985). Hordeins are the major storage proteins of barley endosperm. They are extremely heterogeneous in composition of different barley cultivars, allowing a precise differentiation of genotypes by their protein electrophoretic patterns (Wrigley et al. 1982). Since hordein composition is normally not affected by environmental factors (e.g. growing location, soil types, fertilization level, etc.), hordein electrophoretic composition could be used as a reliable genetic character for cultivar identification (Yan et al. 2003). In barley the grain hordein fraction comprises $40-50 \%$ of the total grain protein. This component is soluble in aqueous alcohol and comprises 4 fractions designated as D, C, B, and A. The diversity in the hordein family has made the analysis of these fractions very useful in varietal identification. Such diversity may be explained through differences within the $\mathrm{B}$ and $\mathrm{C}$ hordeins that occur between varieties, as well as grain protein levels and environments (Fox et al. 2003; Perovic et al. 1998). The aim of this study was to identify barely varieties by using Matrix Assisted Laser Desoption/Ionization Time-Of-Flight Mass Spectrometry (MALDI TOF MS).

\section{MATERIAL AND METHODS}

\section{Barley sampling}

Eight barley varieties, specifically: Kangoo, Laudis, Malz, Marthe, Odyssey, Overture, Sebastian and Wintmalt were investigated in this experiment. One grain from all varieties was milled and weighted. Seventy mg of milled barley flours were used for protein extraction. 


\section{Barley protein extraction}

Hordeins were extracted using a direct method (extraction from flour directly) and a second method following the removal of albumins and globulins with $5 \%$ $\mathrm{NaCl}$. Sixty \% ethanol containing $2 \%$ DTT (dithiothreitol) was used to obtain the hordein fraction. Eight replicates of all barley varieties were prepared. Five hundred $\mu \mathrm{l}$ of extraction solution were added to all samples. The samples were vortexed in Eppendorf tubes for $1 \mathrm{~min}$. After vortexing, centrifugation at 12000 $\mathrm{x} \mathrm{g}$ for 10 min was performed.

\section{MALDI TOF MS barley sample preparation}

One microliter of hordein extracts in extraction solution were transfered into the MALDI 96 plate (Bruker Daltonics, Germany) with eight replicates for all varieties of barley. Overlaying by matrix was done in two ways. The first extract were evaporated at room temperature and second extracts were mixed with matrix in liquid phase. Two MALDI matrices were used in this experiment. One $\mu l$ of HCCA ( $\alpha$-cyano-4-hydroxycinnamic acid) for protein spectra ranging from 4 to $25 \mathrm{kDa}$ and $1 \mu \mathrm{l}$ of SA (sinapinic acid) for protein spectra ranging from 29 to $50 \mathrm{kDa}$ were used. All matrices were prepared by the same procedure $(10 \mathrm{mg} / \mathrm{m}$ particular acid dissolved in acetonitrile/ $0.1 \%$ trifluoracetic acid, $3: 2$, v/v). Finally plate with samples and matrix was dried at room temperature. In addition, the same plate with samples was measured by MALDI-TOF MS two times, firstly immediately following protein isolation and secondly after two weeks.

\section{MALDI TOF MS protocol for barley protein analysis}

Barley protein (hordein) analysis was processed with Microflex LT MALDI-TOF Mass Spectrometer (Bruker Daltonics, Germany) using flexControl 3.0 software (Bruker Daltonics, Germany) operating in positive linear ion mode between $\mathrm{m} / \mathrm{z}$ 29 and 50kDa. Microflex LT was set using flexControl software in following parameters: ion source 1: $20 \mathrm{kV}$, ion source 2: $16.7 \mathrm{kV}$, lens: $6 \mathrm{kV}$, pulsed ion extraction 500ns, detection gain: 3x, electronic gain: regular, mode: low range mass range selection: low range, laser frequency: $60 \mathrm{~Hz}$, digitizer trigger level: $2.500 \mathrm{mV}$, laser attenuator: $24 \%$, laser attenuator: 30\%, laser range: $70-90 \%$. Spectra were measured randomly by 500 laser shots. All of the series of measurement were procceded by calibration with a Protein 2 callibration standard (Bruker Daltonics, Germany) as positive control and pure matrix solution was used as negative control. Obtained spectra were analyzed using flexAnalysis, version 3.4 (Bruker Daltonics, Germany) and MALDI Biotyper, version 3.0 (Bruker Daltonics, Germany).

\section{Quality control for barley varieties identification}

Eight pure barley varieties (Kangoo, Laudis, Malz, Marthe, Odyssey, Overture, Sebastian and Wintmalt) were used to assess the accuracy and level for the MALDI-TOF MS identification using our extraction procedure. Also positive and negative controls were used for the MALDI-TOF MS identification.

\section{Establishment of a local Barley proteins database}

Eight barley proteins extract were used to establish a preliminary local spectrum database. Twenty specific spectra for each of the 8 barley protein extracts were analyzed using the flexAnalysis software, paying special attention to the intrusive pekas and the reproducibility of spectra. Then, accurate spectra were downloaded into MALDI Biotyper 3.0 and used to create a single mean spectrum for each Barley varieties using the Bio-typer MSP creation method with modofication of spectrum range. For the clustering of the Barley varieties in the created database, a mean spectra projection (MSP) dendrogram was constructed with MALDI Biotyper 3.0.

\section{Reproducibility}

Thirty-two random selected barley grain extracts were used blindly to verify the reproducibility of the protein spectrum profile and MALDI-TOF MS identification. The barley grain extracts were processed in eight replicates using the same procedure as earlier described. The obtained spectra were analyzed and compared with our own local created Barley varieties database.

\section{RESULTS AND DISCISSION}

\section{Protein extraction}

For the hordein fraction with regard to the barley variety discrimination, MALDITOF MS was selected. Hordeins are well soluble in aqueous alcohols and buffers containing urea or DTT. Therefore, barley hordeins were extracted by $60 \%$ ethanol containing 2\% DTT. Dithriothreitol (DTT) is a reducing agent, which reduces disulfide bonds both within and between polypeptide chains, improving extraction efficiency of hordeins. Therefore, all obtained spectra showed high quality and reproducibility of signal with visible differentation between hordein fractions. Pre-extraction of hordeins was done by two ways. The first from milled grains directly and second following albumin and globulin removal with 5\% $\mathrm{NaCl}$. It is generally known that pre-extraction methods reduce the complexity of the obtained protein extract. Based on this fact we expected that removing albumins and globulins could lead to improve the barley protein spectra. However, our results showed that pre-extraction method using $5 \% \mathrm{NaCl}$ to remove albumins and globulins does not have any effect on the improvement of barley protein spectrum. Therefore, the mentioned pre-extraction method is not necessary for its subsequent use for MALDI-TOF MS barley protein observation These results are shown in Fig 1.

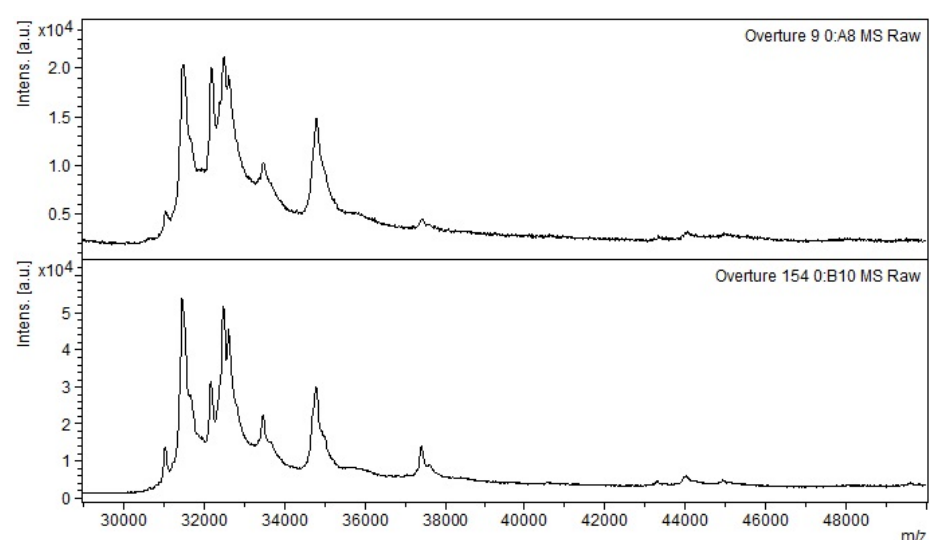

Figure 1 Similarity of hordein spectra from Overture variety obtained using MALDI-TOF MS: (A) pre-extraction method using $5 \% \mathrm{NaCl}$ which removed albumins and globulins and (B) hordein extraction without $\mathrm{NaCl}$ directly from barley flour.

\section{MALDI-TOF MS hordein detection}

The issue about whether the matrix should be mixed with sample hordeins in liquid phase or overlaying after sample drying was discussed. For this purpose two ways of matrix addition were used: the first matrix was mixed with hordeins in liquid phase before drying and the second matrix was overlayed following sample drying. In general, liquid environment is a better phase to mix the chemical compounds when compared to the solid one. On that account, it was expected that mixing matrix with sample in liquid phase could lead to the improvement of hordein mass spectra using MALDI-TOF MS. The comparison of mass spectra of hordeins (Kangoo variety) overlayed and mixed with matrix is shown in Fig 2. There are numerous research studies concerned with overlaying the HCCA matrix in liquid phase or drying in relation to the identification of microorganisms by MALDI-TOF MS (Molina-Cano et al. 2000; Conway et al. 2001; Vargha et al. 2006; Williams et al. 2003; Ruelle et al. 2004; Liu et al. 2007). All authors concluded that the dried droplet approach was the most effective for microbes identification with sample drying followed by overlaying the sample with the matrix (HCCA in acetonitrile/methanol/ (1:1) with $0.1 \%$ formic acid). Our results showed that mixing and overlaying has an effect on the resulting quality spectra of hordeins in barley varieties. This result was found in all our tested barley varieties. Šalplachta and Bobálová mixed $20 \mu$ l hordein extract with $180 \mu \mathrm{l}$ of matrix solution, together $200 \mu 1$ which was dried in SpeedVac centrifuge (Šalplachta and Bobálová 2009). In our experiment we used $1 \mu$ of hordein extract and $1 \mu \mathrm{l}$ of matrix solution and hordein spectrum was analysed without any quality decrease.

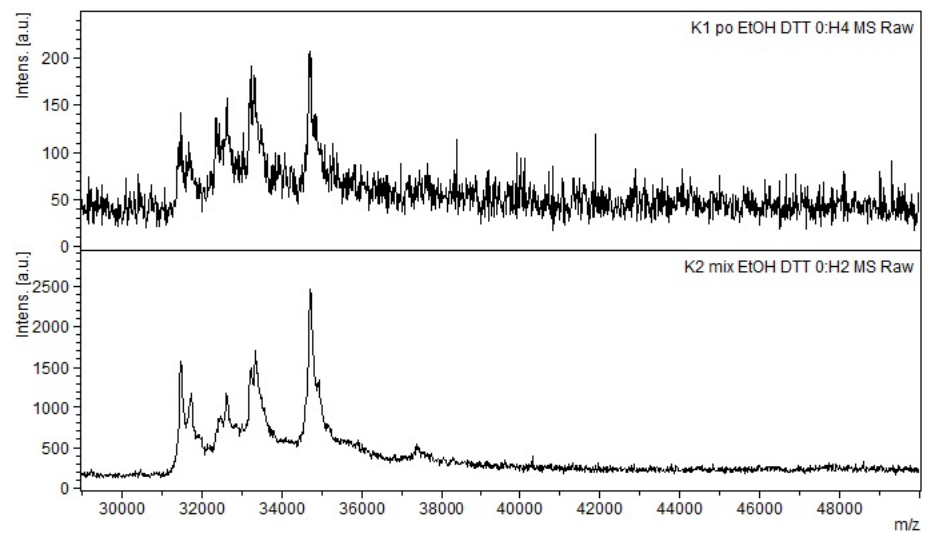

Figure 2 Quality of protein spectrum (Kangoo variety) in relation to (A) overlaying sample with matrix after sample drying and (B) mixing the matrix with sample in a liquid phase 
The influence of time on hordein quality spectrum was also tested. Although the samples were measured immediately after isolation, and there are some possibilities wich may lead to the postponement of work. Therefore, a comparison of quality of spectra measured immediately and after 14 days has been performed. Again, there are many studies where authors investigated the levels of intra-laboratory reproducibility, in which micoorganisms mass spectra were gathered at different times using the same mass spectrometer. Generally, high levels of reproducibility have been reported in relation to the microorganisms' mass spectra. Some authors (Arnold et al. 1999; Bernardo et al. 2002; Smole et al. 2002) noted that when mass spectra were collected over a number of days, or in the case of Bernardo et al. in 2002, months, and peaks were consistently observed in mass spectra for a variety of bacteria (Bernardo et al. 2002). In other cases the authors reported levels of reproducibility of $75 \%$ or higher (Saenz et al. 1999; Walker et al. 2002). Nevertheless no studies were focused on the reproducibility of mass spectra in the case of Barley B hordeins in relation to time. Our results showed that all tested barley hordein samples lost the intensity of mass spectrum signal but not as much as they were unmeasurable. An example of a lost spectrum signal is shown in Fig 3.

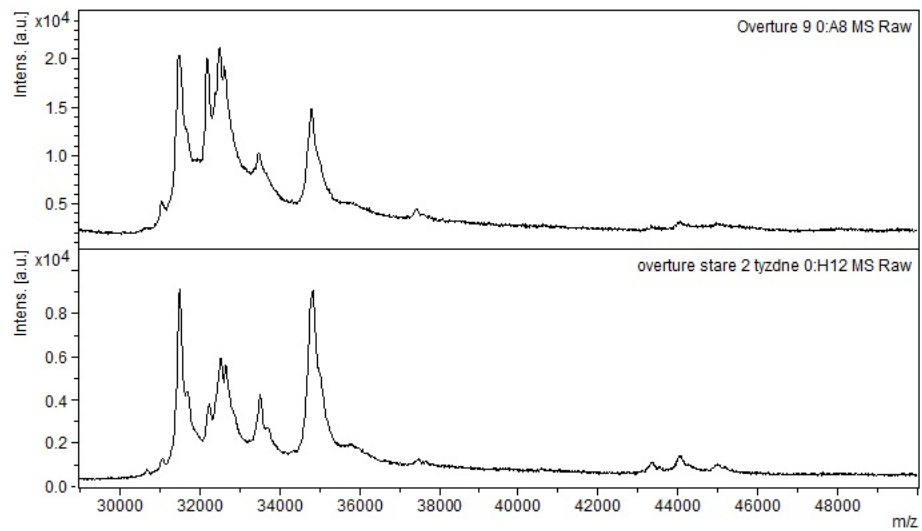

Figure 3 Influence of time on the quality of hordein spectra (Overture variety). (A) Measured hordeins spectrum after isolation immediately and (B) Measured hordeins spectrum after 14 days.

Based on the results of Šalplachta and Bobálová the next isolation of hordeins was done with $60 \%$ ethanol containing $2 \%$ DTT at room temperature (Šalplachta and Bobálová 2009). Also, the pre-extraction of albumins and globulins which was tested in this experiment was not necessary for the varieties of barley. Based on our findings the next preparation of barley samples for MALDI-TOF MS measurement was carried out following isolation immediately and samples were mixed with matrix in liquid phase before drying. Thus, a modified extraction and sample preparation method was applied to all 8 malting barley varieties. The obtained barley hordein extracts and prepared plate samples were analyzed using MALDI-TOF MS. The obtained barley varieties spectra are displayed in Fig 4 and 5. Generally, the hordeins can be divided into four main protein groups: A hordeins with a molecular weight below as $30 \mathrm{kDa}$, B hordein with $\mathrm{m} / \mathrm{z}$ ranging from 30 to $50 \mathrm{kDa}, \mathrm{C}$ hordeins with $\mathrm{m} / \mathrm{z}$ ranging from 50 to 75 $\mathrm{kDa}$ and $\mathrm{D}$ hordeins with a molecular weight above as $90 \mathrm{kDa}$. In accordance with previous findings (Laštovičková et al. 2010), no mass differences between A hordeins were found. All mass signals were distributed into four main groups at around $6 \mathrm{kDa}, 9 \mathrm{kDa}, 12.5-14.5 \mathrm{kDa}$ and $15.5-17 \mathrm{kDa}$ (Fig. 4). Therefore, they can not be used for barley variety discrimination. Conversely, differencies between $\mathrm{B}$ hordeins were significant and they have been used for the discrimination and creation of the local database of barley variety. B hordeins showed three main groups of mass spectrum: from $31-36 \mathrm{kDa}$, at around 38 $\mathrm{kDa}$ and from $43-47 \mathrm{kDa}$. Mass spectrum range from $31-36 \mathrm{kDa}$ were found in all tested barley varieties, mass spectrum at around $38 \mathrm{kDa}$ was found in two varieties (Malz and Wintmalt) only. A mass spectrum range from $43-47 \mathrm{kDa}$ was found in the Overture variety only. Also Laštovičková et al. in 2010 monitored the process of glycation during the malting process and compared two hulled barley varieties to the hulless line KM 1910. Their results showed that the protein patterns did not differ significantly between the three varieties of the barley grains, but ignificant differences between the malts were evident. These major barley proteins are very important for the formation and stability of beer foam and glycation may prevent their precipitation (Shewry et al. 1978). In our study the evaluation of B hordeins showed that they may used for barley variety discrimination and local barley database building. Some detected mass spectra common for all tested barley samples, but unique sets of protein spectra were detected in each barley variety.

\section{Quality control for barley variety identification by MALDI-TOF MS}

In all studies, the positive controls obtained the expected mass spectrum profile (Protein 2 callibration standard) and negative controls (pure matrix) remained negative. Three reference proteins, specifically Protein A [M+2H]2 with 22.307
kDa, Trypsinogen $[\mathrm{M}+\mathrm{H}]$ with $23.982 \mathrm{kDa}$ and Protein A [M+H] $44.613 \mathrm{kDa}$ were correctly detected.

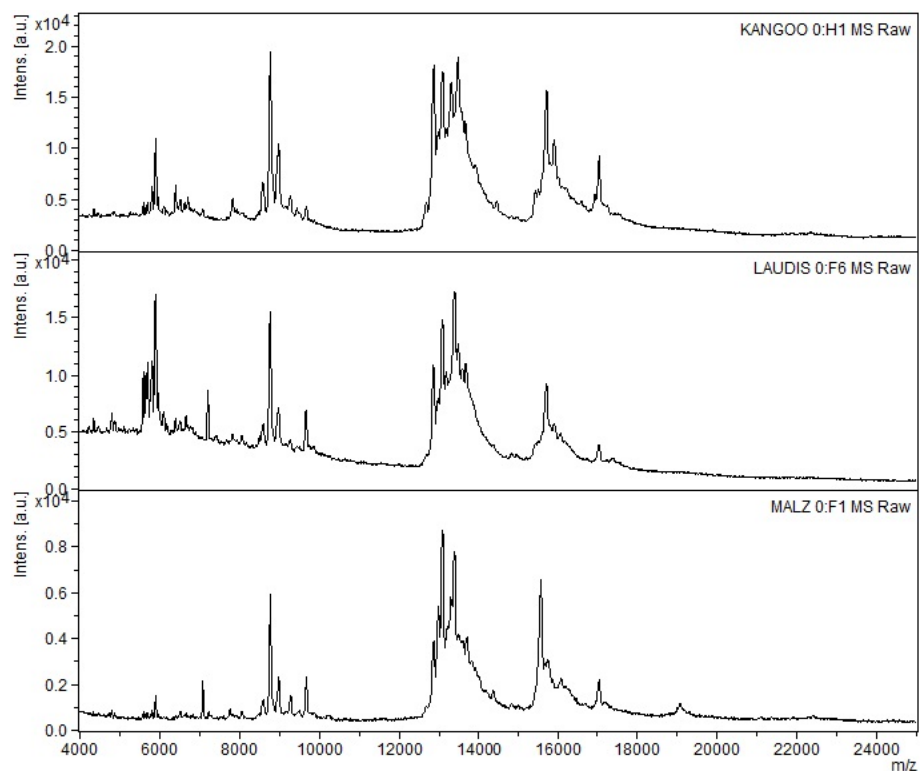

Figure 4 Groups of hordein mass spectrum below $30 \mathrm{kDa}$, ranging from 4 to 25 $\mathrm{kDa}$ of three tested barley varieties (Kangoo, Laudis, Malz)
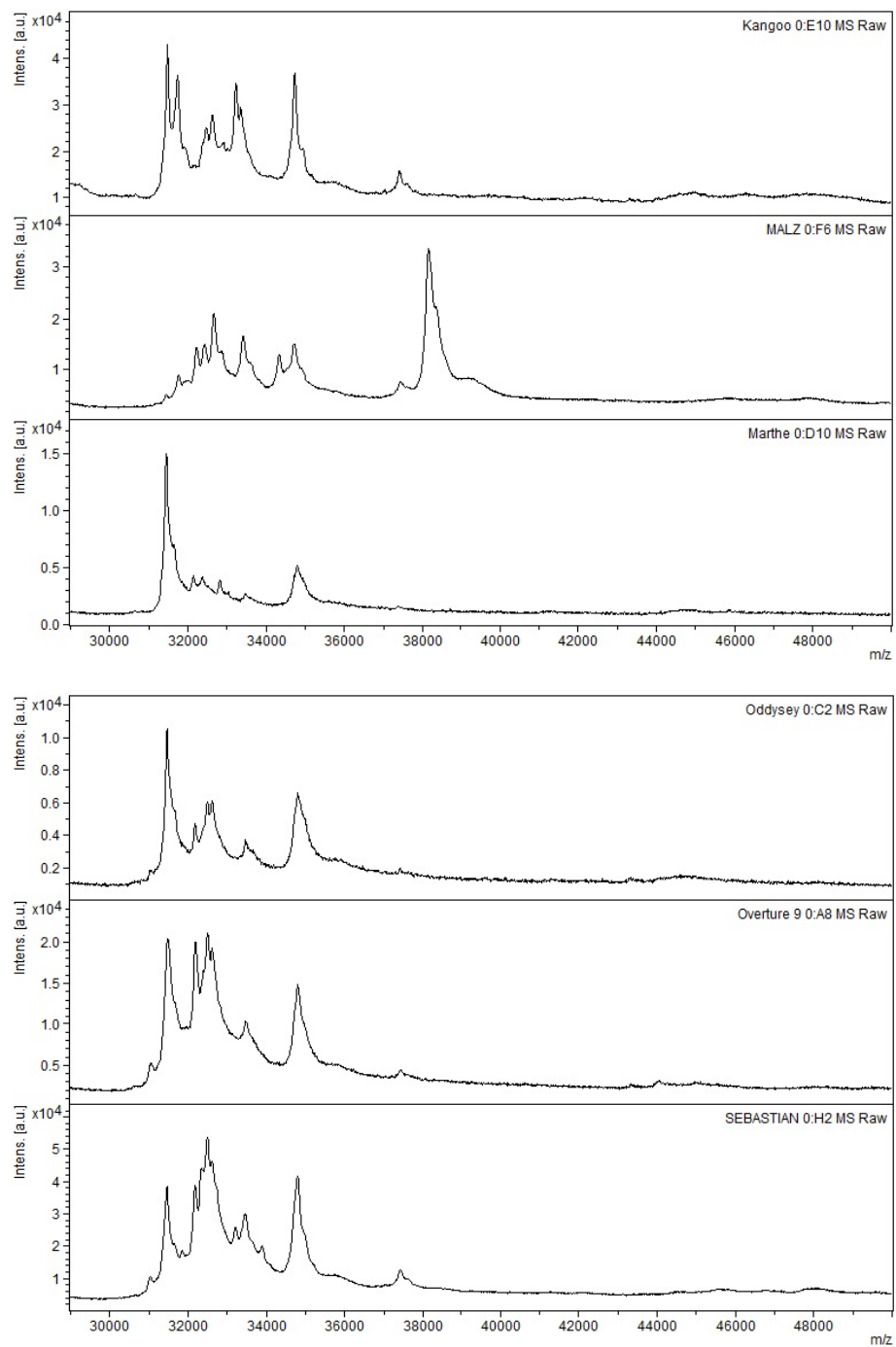


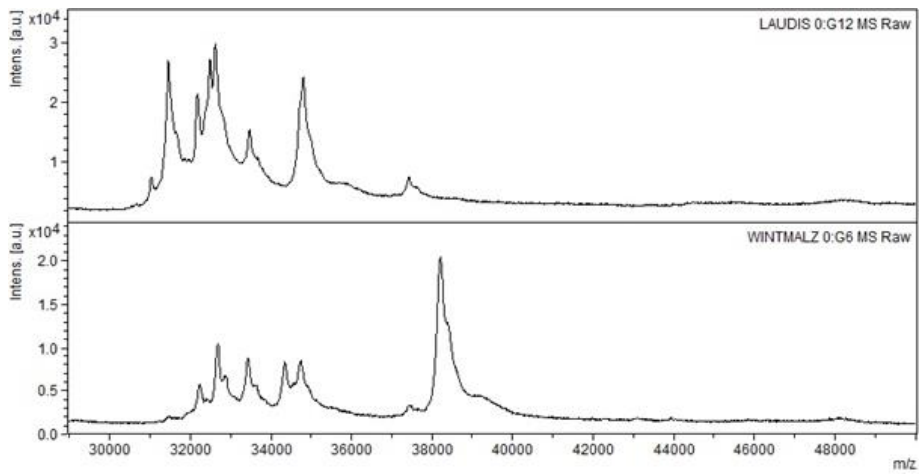

Figure 5 MALDI-TOF MS spectra of all tested barley varieties (Kangoo, Laudis, Overture, Malz, Wintmalt, Sebastian, Oddysey and Marthe)

\section{MALDI-TOF MS analysis and establishment of a local Barley database}

The protein spectra of each of the 8 studied barley varieties showed signal intensities in the mass range of $29-50 \mathrm{kDa}$ which corresponds to B hordeins. The spectra of various barley varieties of the same barley variety were compared, and the presence of all specific obtained protein peaks was confirmed in all of the barley varieties of the same barley variety with a very high reproducibility (Fig 6). These obtained and selected spectra were used to build the database. Loucif et al. in 2014 described the MALDI-TOF MS analysis and establishment of a local Streptomyces database (Loucif et al. 2014). They noted that the purity of mass spectrum for each sample that will be transferred to Maldi Biotyper MSPs is necessary and these should be evaluated by mass spectrum analysis software firstly. Our Barley mass spectra were observed by the flexAnalysis software before the MSP creation process. Microorganisms and Barley mass spectra require a different approach. Where, MALDI-TOF Biotyper was established priority for microbes' identification with mass spectrum ranging from $2 \mathrm{kDa}$ to $21 \mathrm{kDa}$, Barley mass spectra ranging from $29 \mathrm{kDa}$ to $50 \mathrm{kDa}$ and they requires different settings of MALDI-TOF Biotyper.
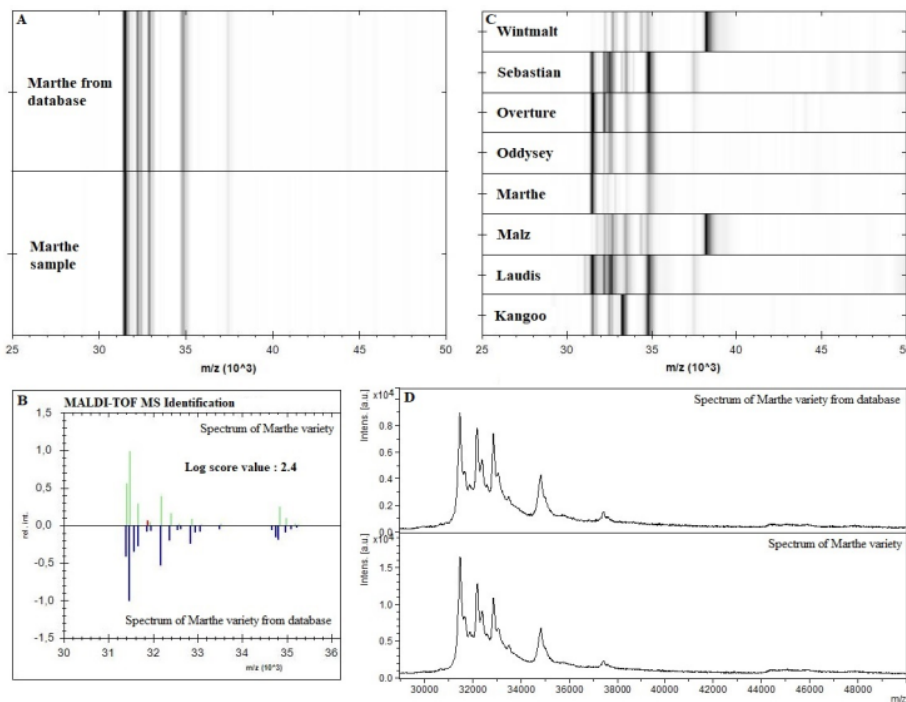

Figure 6 Comparison of B hordein spectrum profile of Barley varieties. (A) Alignment of two Barley B hordein mass spectra in Fig. 6D (virtual gel view) showing the high reproducibility of mass spectra for the same barley variety (Marthe) using MALDI Biotyper software, version 3.1 (Bruker Daltonics, Germany). (B) MALDI-TOF MS Identification of Barley variety (Marthe) showing a high reliable identification value (score at 2.4) using MALDI Biotyper software, version 3.1 and our builded barley database. (C) Virtual gel view of 8 different Barley variety mass spectra showing barcode of masses and their signal intensity specific for each barley variety using MALDI Biotyper software, version 3.1. (D) Comparison of two B hordein spectra of Barley variety (Marthe) from our local Barley database and that of the reproducubility test. $\mathrm{m} / \mathrm{z}$ - mass to charge ratio.

\section{Reproducibility}

All (100\%) of the 32 blindly selected barley varieties were already present in our database, and these were correctly identified to the exact variety, with scores ranging from 2.13 to 2.84. Similarity between some Barley varieties can lead to a low identification of the Log score. A correct set up of the identification procedure in the Maldi Biotyper software is necessary. Relations between the barley varieties based on B hordeins detected using MALDI-TOF MS is showed in Fig 7.

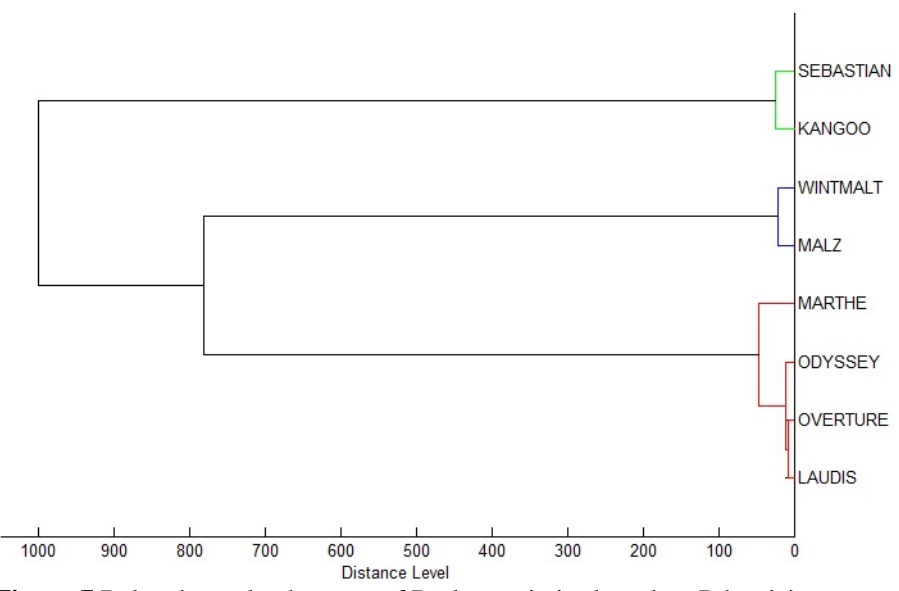

Figure 7 Relatedness dendrogram of Barley varieties based on B hordeins

\section{CONCLUSION}

Generally, all hordein fractions, especially B hordeins can be used for Barley varieties discrimination. Overally, eight Barley varieties were examined in this research and eight different and unique B hordein mass spectra were observed using MALDI-TOF MS. Extraction of hordeins for MALDI-TOF MS is a simple method where $60 \%$ of ethanol containing $2 \%$ DTT were used. Pre-extraction of albumins and globulins with $5 \% \mathrm{NaCl}$ is not necessary, as the resulting mass spectra are very similar. The way to apply the matrix seems to be important Mixing of matrix with sample in liquid phase can lead to the improvment of spectra. The time between sample preparation and measurement seems to be important too. The intesity of signal decreases with time. A hordeins isolated from milled barley grains did not show a high differentation. Therefore, barley database was built from the high specific B hordein spectra. Establishment of the barley database must be based on very high reproducibility of hordein spectra and the quality of each spectra must be verified by software. Very close related barley varieties can cause problems with the identification. Therefore, a correct obtention of quality barley hordein spectra can lead to a correct identification. Barley varieties show specific and unique sets of proteins which can be detected by MALDI-TOF MS with high accuracy. This procedure is cheap and quick, particularly in comparison to the gel electrophoresis. Our results suggest that MALDI-TOF MS could be a good method for a quick and cheap identification of barley varieties, which are very important for the malting and brewing industry.

Acknowledgement: This study was founded by European Community under project no. 26220220180: Building Research Centre „AgroBioTech" and by the Slovak Research and Development Agency grant no. APVV-15-0544.

\section{REFERENCES}

Arnold, R. J., Karty, J. A., Ellington, A. D., \& Reilly, J. P. (1999). Monitoring the growth of a bacteria culture by MALDI-MS of whole cells. Analytical Chemistry, 71(10), 1990-1996. https://doi.org/10.1021/ac981196e

Bernardo, K., Pakulat, N., Macht, M., Krut, O., Seifert, H., Fleer, S., ... \& Krönke, M. (2002). Identification and discrimination of Staphylococcus aureus strains using matrix-assisted laser desorption/ionization-time of flight mass spectrometry. Proteomics, 2(6), 747-753. https://doi.org/10.1002/16159861(200206)2:6<747::aid-prot747>3.0.c0;2-v

Conway, G. C., Smole, S. C., Sarracino, D. A., Arbeit, R. D., \& Leopold, P. E. (2001). Phyloproteomics: species identification of Enterobacteriaceae using matrix-assisted laser desorption/ionization time-of-flight mass spectrometry. Journal of molecular microbiology and biotechnology, 3(1), 103112.

Eagles, H. A., Bedggood, A. G., Panozzo, J. F., \& Martin, P. J. (1995). Cultivar and environmental effects on malting quality in barley. Australian Journal of Agricultural Research, 46(5), 831-844. https://doi.org/10.1071/ar9950831

Fox, G. P., Panozzo, J. F., Li, C. D., Lance, R. C. M., Inkerman, P. A., \& Henry, R. J. (2003). Molecular basis of barley quality. Australian Journal of Agricultural Research, 54(12), 1081-1101. https://doi.org/10.1071/ar02237

Izydorczyk, M. S., \& Edney, M. (2017). Barley: Grain-Quality Characteristics and Management of Quality Requirements. In Cereal Grains (pp. 195-234). Woodhead Publishing. https://doi.org/10.1016/b978-0-08-100719-8.00009-7

Laštovičková, M., Mazanec, K., Benkovská, D., \& Bobál'ová, J. (2010). Utilization of the linear mode of MALDI-TOF mass spectrometry in the study of glycation during the malting process. Journal of the Institute of Brewing, 116(3), 245-250. https://doi.org/10.1002/j.2050-0416.2010.tb00427.x

Liu, H., Du, Z., Wang, J., \& Yang, R. (2007). Universal sample preparation method for characterization of bacteria by matrix-assisted laser desorption ionization-time of flight mass spectrometry. Appl. Environ. Microbiol., 73(6), 1899-1907. https://doi.org/10.1128/aem.02391-06 
Loucif, L., Bendjama, E., Gacemi-Kirane, D., \& Rolain, J. M. (2014). Rapid identification of Streptomyces isolates by MALDI-TOF MS. Microbiological research, 169(12), 940-947. https://doi.org/10.1016/j.micres.2014.04.004

Molina-Cano, J. L., Polo, J. P., Sopena, A., Voltas, J., Pérez-Vendrell, A. M., \& Romagosa, I. (2000). Mechanisms of malt extract development in barleys from different European regions: II. Effect of barley hordein fractions on malt extract yield. Journal of the Institute of Brewing, 106(2), 117-124. https://doi.org/10.1002/j.2050-0416.2000.tb00048.x

Montembault, A., Autran, J. C., Joudrier, P., \& Moll, M. (1983). Varietal identification of barley and malt. Journal of the Institute of Brewing, 89(4), 299302. https://doi.org/10.1002/j.2050-0416.1983.tb04189.x

Perovic, D., Yan, Y., Prodanovic, S., Vracarevic, M., \& Zoric, D. (1998) Characterization of spring barley cultivars by hordein seed storage protein analysis. Barley and Wheat Newsletter. https://doi.org/10.2298/gensr0903271p

Ruelle, V., Moualij, B. E., Zorzi, W., Ledent, P., \& Pauw, E. D. (2004). Rapid identification of environmental bacterial strains by matrix-assisted laser desorption/ionization time-of-flight mass spectrometry. Rapid Communications in Mass Spectrometry, 18(18), 2013-2019. https://doi.org/10.1002/rcm.1584

Saenz, A. J., Petersen, C. E., Valentine, N. B., Gantt, S. L., Jarman, K. H., Kingsley, M. T., \& Wahl, K. L. (1999). Reproducibility of matrix-assisted laser desorption/ionization time-of-flight mass spectrometry for replicate bacterial culture analysis. Rapid communications in mass spectrometry, 13(15), 15801585. $\quad$ https://doi.org/10.1002/(sici)1097-0231(19990815)13:15<1580::aidrem679>3.0.co;2-v

Šalplachta, J., \& Bobálová, J. (2009). MALDI-TOF mass spectrometry of hordeins: rapid approach for identification of malting barley varieties. Journal of mass spectrometry, 44(9), 1287-1292. https://doi.org/10.1002/jms.1606

Shewry, P. R., Faulks, A. J., Parmar, S., \& Miflin, B. J. (1980). Hordein polypeptide pattern in relation to malting quality and the varietal identification of malted barley grain. Journal of the Institute of Brewing, 86(3), 138-141. https://doi.org/10.1002/j.2050-0416.1980.tb03974.x

Shewry, P. R., Kreis, M., Parmar, S., Lew, E. L., \& Kasarda, D. D. (1985) Identification of $\gamma$-type hordeins in barley. FEBS letters, 190(1), 61-64. https://doi.org/10.1016/0014-5793(85)80427-0

Shewry, P. R., Pratt, H. M., \& Miflin, B. J. (1978). Varietal identification of single seeds of barley by analysis of hordein polypeptides. Journal of the Science of Food and Agriculture, 29(7), 587-596. https://doi.org/10.1002/jsfa.2740290703

Smole, S. C., King, L. A., Leopold, P. E., \& Arbeit, R. D. (2002). Sample preparation of Gram-positive bacteria for identification by matrix assisted laser desorption/ionization time-of-flight. Journal of microbiological methods, 48(23), 107-115. https://doi.org/10.1016/s0167-7012(01)00315-3

Vargha, M., Takáts, Z., Konopka, A., \& Nakatsu, C. H. (2006). Optimization of MALDI-TOF MS for strain level differentiation of Arthrobacter isolates. Journal of microbiological methods, 66(3), 399-409. https://doi.org/10.1016/j.mimet.2006.01.006

Walker, J., Fox, A. J., Edwards-Jones, V., \& Gordon, D. B. (2002). Intact cell mass spectrometry (ICMS) used to type methicillin-resistant Staphylococcus aureus: media effects and inter-laboratory reproducibility. Journal of microbiological methods,48(2-3), 117-126. https://doi.org/10.1016/s01677012(01)00316-5

Williams, T. L., Andrzejewski, D., Lay, J. O., \& Musser, S. M. (2003). Experimental factors affecting the quality and reproducibility of MALDI TOF mass spectra obtained from whole bacteria cells. Journal of the American Society for Mass Spectrometry, 14(4), 342-351. https://doi.org/10.1016/s10440305(03)00065-5

Wrigley, C. W. (1992). Identification of cereal varieties by gel electrophoresis of the grain proteins. In Seed analysis (pp. 17-41). Springer, Berlin, Heidelberg. https://doi.org/10.1007/978-3-662-01639-8_2

Yan, Y., Jiang, Y., Yu, J., Cai, M., Hu, Y., \& Perovic, D. (2003). Characterization of seed hordeins and varietal identification in three barley species by high-performance capillary electrophoresis. Cereal Research Communications, 31(3/4), 323-330. 